\title{
"Er feminismen en død sild?"
}

\section{DEBAT}

\author{
Af Kirsten HyldgaArd
}

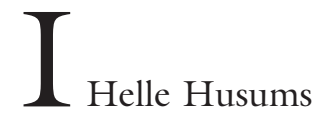

debatindlæg "Er feminismen en død sild?" fra Kvinder, Kon og Forskning, 1. 98, s. 77ff. hedder det: “At 'kvinden' ikke eksisterer, og at subjektet er dødt, er efterhånden gamle nyheder." Srtningen, at "Kvinden ikke eksisterer", har tilsyneladende fået status af floskel.

Der er ikke ophavsret til viden, sætninger, teser eller pointer, men ofte tilskrives sætningen Lacan. Det er ikke Lacan, H.H. udlægger, men når jeg i det følgende vil præcisere, hvad sætningen betyder hos Lacan og især, hvad den ikke betyder, kan jeg herved bidrage til debatten omkring, hvorledes kønsforskellen kan tænkes.

"Kvinden" er ikke et universale eller et almenbegreb. Det er ikke muligt at udpege træk i forhold til hvilke, vi ville kunne indrullere et værende i mængden af "kvinder". Der findes ikke nogen lov, der kan afgrænse mængden kvinder, en lov der kan udpege, hvad kvinder er til forskel fra mænd. Det er H.H. og jeg formentlig ikke uenige i, og det er sikkert en gammel nyhed. Denne pointe resulterer imidlertid i humanistisk individualisme og voluntarisme hos H.H.: 
"Selvom jeg afviser kategorierne "mandlig" og "kvindelig" er de stadig bestemmende for mit liv. - Om jeg vælger at identificere mig med dem eller afviser dem som relevante for mig." (s. 79.) Kønnet er "performance". Jeg kan "spille mit "kvindekøn'“, jeg kan "lege” og vise at jeg er "både-og", jeg kan "vælge" at identificere mig med det ene eller det andet. Det har transvestitter, transseksuelle og homoseksuelle også altid insisteret på retten til at gøre. Er disse blevet norm for politikken? Det understreges, at "hermed er det ikke sagt, at det er muligt frit at vælge sit køn. Jeg hænger på det "kvindekøn", som min biologiske krop indtil videre (!) forudsætter, men det er, hvordan jeg velger at forholde mig til det, der kan være en form for modstand, hvordan jeg vælger at gentage det ..." Her lyder der klassisk eksistensfilosofiske og humanistiske toner, at 'det afgørende ikke er, hvad de andre gør mig til, men hvad jeg gør med det, de andre gør mig til.' Hvis det er en gammel nyhed, at subjektet er dødt, hvad er det så, der vælger at lege og at spille? Der skal ikke herske tvivl om, at jeg anser en sådan humanisme og voluntarisme for at være en illusion.

Det ovennævnte har intet med Lacans diktum om, "at kvinden ikke eksisterer", at skaffe. Den almindelige misforståelse af pointen består i at identificere det ubestembare med det androgyne. Forestillingen eller fantasmet om det androgyne vidner imidlertid om en viden om, hvori kønsforskellen består, ellers ville man ikke kunne være mereeller-mindre og både-og. I begge ender af den én-dimensionelle androgyne akse, har vi det ur-kvindelige og det ur-mandlige, der kan give kønnet mening eller betydning. Ethvert subjekt er således placeret et variabelt sted på denne akse, og kønsforskellen er følgelig ikke ubestemt i talen om det androgyne eller tvekønnede individ. Kvinden eksisterer i bedste ur-kvindelige velgående for enden af aksen.

Det ubestembare, det uidentificerbare, det uafgrænselige er imidlertid i psykoana- lysen forskellige navne for det forhold, at kønnet anfægter forestillingen om såvel almenbegrebet menneske, fantasmet om det ikke-kønnede eller androgyne, tvekønnede menneske, som den klassiske komplementære model, hvor kønsforskellen er binære, symmetriske oppositioner. Ideen om komplementaritet mellem kønnene viser sig eksempelvis i talen om, at vi kan lege og vælge i cyberspace at være mænd i stedet for kvinder og omvendt. Nogle anser dette for at være en frigørende mulighed og derfor som noget, der også hvad angår det biologiske, anatomiske køn burde være en menneskeret. Det er kun "indtil videre", at det biologiske køn er noget, "vi hænger på". (op.cit.)

Ifølge psykoanalysen er dette en illusion, der er karakteriseret ved at fornægte netop kønsforskellen som en irreducibel betingelse for at blive et subjekt, og det er en forestilling, der henter model i transvestittens omgang med kønnet. Jeg noterede mig, da jeg læste sidste nummer af Kvinder, Køn og Forskningl at man her taler om "computer crossdressing" (s. 27) og "gender swapping". Hvad er der i vejen med det gode gamle 'transvestit'? Hvorfor vil man ikke omtale en bestemt praksis på internettet nemlig at give sig ud for at være det andet køn - som transvestittens praksis? Cyberspace eller internettet skaber eller bekræfter tilsyneladende illusionen om, at kønsforskellen drejer sig om komplementære størrelser eller binære, symmetriske oppositioner, som vi herefter kan "swappe" imellem, at der findes bestemte betydninger af køn på baggrund af hvilke, vi kan foregive at være det andet køn, at vi kan vide, hvad det vil sige at være kvinde, henholdsvis mand og derfor 'gå for' at være det ene eller det andet køn i cyberspace.

Men en første tvivl kan sås ved hjælp af spørgsmålet: Kan kvinder være transvestitter? Kvinder kan klæde sig og har altid klædt sig og optrådt ifølge med tiden skiftende konventionelle rstetiske normer for og konstruktioner af maskulin fremtræden 
og derefter blevet kaldt mandhaftige eller pirrende androgyne - Marlene Dietrich er skoleeksemplet. Men kan kvinder være transvestitter? Psykoanalytikeres og sexologers benægtende svar på og tvivl $\mathrm{i}$ forhold til dette spørgsmål vidner om, at kønsforskellen ikke umiddelbart eller uden tvivl kan tænkes som forudgivne og komplementære betydninger, der kan "swappes" imellem. Spørgsmålet sår tvivl om, der overhovedet kan vides om kvindeligheden, om kvindeligheden og dermed kønnet overhovedet har en betydning - ikke i betydningen er lige-gyldigt eller lige-meget, som nogle har en drøm om, men i betydningen, at kvindeligheden ikke er noget, der kan "have" en betydning. Kønnet og Kvinden er ifølge psykoanalysen snarere det, der vedholdende og ahistorisk viser inkonsistensen og sammenbruddet i de historisk, variable, metonymisk glidende betydninger af køn. Derfor "eksisterer" hun ikke, for med eksistens menes, at hun ikke kan repræsenteres, ikke kan finde en plads i det symbolske.

Alle repræsentationer af kønsforskellen er formentlig variationer over de ovennævnte to grundlæggende modeller, hvis eksistensberettigelse er at give kønnet mening eller betydning og altså forskellige mulige løsninger på den "umulighed" og grundlæggende konfliktuelle status kønnet har.

"The Construction of Gender ..." er for tiden en af de almindeligste formuleringer $\mathrm{i}$ titler på foredrag og artikler omkring spørgsmålet om køn, som 'socialkonstruktivisme' er omdrejningspunkt i den filosofiske debat overhovedet. At der i psykoanalysen tales om kønnet som en grundlæggende irreducibel konflikt skyldes, at spørgsmålene om drift, seksualitet og køn hverken kan reduceres til et spørgsmål om biologi eller til et spørgsmål om historisk variable, diskursive repræsentationer eller konstruktioner. Køn, seksualitet og drift er snarere det, der nødvendigvis modsætter sig repræsentation og harmoniserende mening, og som ikke mindst hvad driftsbegrebet an- går modsætter sig en indplacering $\mathrm{i}$ forhold til en biologisk essentialisme på den ene side og en kulturel konstruktion på den anden. Køn, seksualitet og drift er "reelt" i og med, at det er 'det', som afstedkommer meningens og dermed konstruktionernes kollaps. Alle repræsentationer af kvindeligheden - som de måtte findes blandt manifest heteroseksuelle, homoseksuelle mænd og kvinder, transvestitter og transseksuelle - er forskellige løsninger på denne grundlæggende konflikt.

Ved hjælp af logiske notationer søger Lacan at vise kønnets paradoksale, asymmetriske og umulige status som betingelse for subjektivitet. Subjektet er ikke spor "dødt" hos Lacan, for det har ikke så lidt med denne meningens og konstruktionernes kollaps at gøre, når "spillet" og "legen" altså ikke længere er god. Et subjekt er defineret som en "mangel-på-væren", hvilket er noget ganske andet end et psykologisk 'jeg' eller filosofisk subjekt i betydningen grund. Kønnet er ikke et værende, men 'er' i kraft af at være fundamentalt "umuligt" en betingelse for at blive et subjekt hos Lacan og derfor ikke blot et appendiks til et humanistisk menneske, der skulle kunne vælge at skabe sig på den ene eller den anden måde. Kønnet er det, der ikke kan forklares ved og reduceres til et andet værende, kaldet biologi eller historisk variable konstruktioner. Heraf det irreducible. Race, religion, etnicitet og nationalitet er eksempler på reducible størrelser, altså identifikationspunkter, der sikkert restløst kan reduceres til at være historisk variable, diskursive konstruktioner. Kønnet er derimod en 'ahistorisk' betingelse for at være i verden - som døden, denne anden irreducible, reelle og meningsløse betingelse for at være i verden.

Uanset hvilken model eller repræsentation af kønsforskellen, der er tale om, skaber den mening i galskaben, dvs. er en måde, hvorpå den ellers irreducible konflikt kan tildækkes og glattes ud. Transvestitter og transseksuelle har det til fælles, at de mener at vide, hvad det vil sige at være en kvinde; 
de fornægter kønsforskellen netop ved at vide, hvori kvindeligheden består, ved at tildække kønnet med betydninger. Kvindeligheden og kønsforskellen er ikke længere et spørgsmål, altså en mangel på viden. Det er påfaldende, at de betydninger af køn, vi præsenteres for hos transvestitter og transseksuelle, er uhyre konforme og stereotype betydninger. Konstruktivismens fortjeneste er uden tvivl at have vist, at i modsætningen mellem biologisk køn og socialt køn er det biologiske også altid-allerede en social konstruktion. I tvangen til enten om- og udklædning eller kirurgiske indgreb synes modsætningen mellem "sex" og "gender" imidlertid blot at blive bekræftet og konserveret. Derfor forekommer det mig - også politisk - vigtigt, om H.H's humanisme kan skelnes fra såvel transvestitters "performance", "spil” og "leg" som transseksuelles krav om retten til at vælge køn. Hvis dét er blevet norm for kønspolitik, er det vel en overvejelse værd.

Kirsten Hyldgaard

adjunkt, Ph.D.

CEKVINA, Arhus Universitet

1. nr 1/1998 tema "Køn i Cyberspace", København 1998. 